\title{
Study on the Strategy of Social Policy Integration in the Construction of the Yangtze River Delta City Group
}

\author{
Xingke $\mathrm{Bi}^{1}$, Kai $\mathrm{Yu}^{2}$ \\ ${ }^{1}$ Shanghai University of Engineering Science, China \\ ${ }^{2}$ Shanghai University of Engineering Science, China \\ Correspondence: Xingke Bi, Shanghai University of Engineering Science, China.
}

Received: November 24, 2016

Accepted: December 16, $2016 \quad$ Available online: December 26, 2016

doi:10.11114/ijsss.v5i2.2107

URL: http://dx.doi.org/10.11114/ijsss.v5i2.2107

\begin{abstract}
"The development plan of Yangtze River Delta city group" puts forward to promote the construction of the Yangtze River Delta city group and speed up the optimization and upgrading of the Yangtze River Delta city group. How to achieve social policy integration is the key to the construction of the Yangtze River Delta city group. This paper analyzes the factors that hinder the social policy integration of the Yangtze River Delta city group from employment, social security, health care, education and housing security and other aspects. Then we use the welfare pluralism theory to analyze the obstacles from the government, the society and the family of three subjects, and put forward the corresponding measures to solve the problems.
\end{abstract}

Keyword: Yangtze River Delta city group, social policy, integration, welfare pluralism theory

\section{Research Background}

In 13th Five-Year planning puts forward to the construction of the Yangtze River delta city group of world-class and enhances the level of open competition in the domestic city group. Planning raises to establish a sound urban agglomeration development and coordination mechanism, promote inter regional division of labor, infrastructure, ecological protection, environmental governance and coordination linkage and achieve the integration of urban agglomeration and efficient development. "The development plan of Yangtze River Delta city group" puts forward to promote the construction of the Yangtze River Delta city group, pad short board, eliminate bottlenecks, improve the international competitiveness and sustainable development ability (Finance and Economics, 2016). At present, the construction of the Yangtze River Delta city group has entered the transition period. To achieve the integration of the social policy of different cities in the Yangtze River Delta is the key to achieve the success of the transformation of city group.

As China's market economy is still in the initial stage, the government functions have not been completely changed, and the regional protectionism still exists. So we want to achieve the integration of social policy in the Yangtze River Delta, the resistance is quite large. We have to talk from employment, social security, health care, education and housing security and other five aspects of the analysis of the obstacles to realize the integration of social policy. Based on the theory of welfare pluralism, this paper talks reasons from the government, the society and the family of three subjects, and put forward the corresponding measures to promote the social policy integration of the Yangtze River Delta city group.

\section{Academic Research Results}

This paper focuses on how to realize the integration of social policy in the Yangtze River Delta city group. Through the analysis of the academic achievements, this paper will briefly describe the two aspects of the implementation of regional integration and policy integration.

\subsection{Relevant Research Results on Regional Integration}

Under the premise that the regional contact is more closely and the social governance is more dynamic, the scholars have carried out a lot of research on how to realize the regional integration.

The first point of view is from the perspective of the government. Jiang Zhiting and Jiang Lin thought that we should 
play the role of government regulation from the perspective of financial expenditure (Lin, J. R., \& Jiang, 2008). Gu Songnian believed that the central government should do a good job to make a clear top-level design, and guide the rational allocation of resources in the city (Gu Songnian, 2015).

The second point is the innovation of institutional mechanisms. Feng Nianhua proposed to break the traditional barriers of institutional mechanisms through market mechanism and innovation management mechanism to promote regional integration (Feng, N, 2004). Xie huijuan and Wang Weiping believed that regional integration needs the central and local governments, the central and local enterprises, the central and local non-governmental organizations to participate actively in all kinds. It is necessary to solve the problem regional coordinated development through the establishment of long-term interests of the coordination mechanism (Xie, H. J., \& Wang, W. P, 2016).

The third point is the system integration. Tong Baoquan and Chen Cai proposed regional system integration mode. We can break the idea of region standard based on non-cooperative game to promote regional integration through the system integration (Tong, B. Q. \& Chen, C, 2006). Li Jianyu believed that the integration and innovation ofmanagement mechanism and policy can promote regional integration (Li, J. Y, 2009).

The fourth view is the establishment of non-governmental organizations. Liu Zezhao and Wang Juanli made great efforts to foster and support non-governmental organizations, such as the City Union Chamber of Commerce and industry associations and other organizations, to become the regional fusion of the 'booster' (Liu, Z. Z., \& Wang, J. L, 2012). Lv Lachang and Xu Guoqiang proposed the establishment of organizations outside the government, which can be given the comprehensive management of the power, to force the implementation of regional development and management (Lv Lachang, \& Xu, G. Q, 1999).

The sixth idea is to play the role of science and technology. Xu Wanqiang and DuanXuan proposed the idea of collaborative technology to promote the cooperation of all levels of society and economy. It can help achieve the development of the city group economic and social goals (Xu, W. Q., \&Duan, X, 2014). Fang Dachun and Sun Mingyue believed that high iron can play a great role for the condensation of space resources in the city. It can accelerate the movement of the adjustment of industrial structure and promote the regional integration process (Fang, D. \& Sun, M. Y, 2015).

\subsection{Relevant Research Results on Policy Integration}

The relevant literature on how to achieve the policy integration is lack. Scholars generally believed that it needs to play a social and civil society to achieve the integration. Cai Yinghui believes that we need to construct compatibility policy network system, introduce the civil power and establish a partner system which can be cross regional, cross sectoral and cross level (Cai, Y. H, 2012).Chen Haotian emphasized the importance of civic and social participation. He putted forword to strengthen the interactive process of social demands and governance to promote the integration of policies (Chen, H. T, 2014).

In summary, the academic circles have more than six viewpoints on how to realize regional integration, and further analysis found that the scholars putted forward integration suggestions from the government, market and society on how to play the role of the three party. However, the research on specific social policy integration in specific areas is still relatively less. This paper is dedicated to promote social policy integration in the Yangtze River Delta city group. we should analyze what the differences are between the cities in social policy. Then we find out the deeper reason to help solve the problems.

\section{Welfare Pluralism Theory}

Welfare pluralism refers to that the regulation and financing are provided by different departments (Peng, H. M, 2009). Different from the traditional liberalism and nationalism, welfare pluralism emphasizes participation, and it is a new paradigm in the study of social policies.

The welfare pluralism theory emphasizes that the country is one aspect of citizen welfare sources. Welfare should be the product of the whole society, and it is a comprehensive welfare provided by multiple subjects. So the welfare subject should include state, society and family.

Today, the studies of social policy and welfare are closely related. The total amount of welfare is equal to the welfare of the family production, coupled with the welfare provided by the market transaction and the welfare provided by the state. Therefore, to study the integration of social policy, this is from the government, society and family and other main body to analyse the role of each subject.

\section{Obstacles in the Integration of Social Policy in the Yangtze River Delta Urban Agglomeration}

\subsection{The Development of Job Markets Is Different}

In twenty-first Century, China gradually changed the development strategy. How to ensure adequate employment has been 
become a focus of concern for the local government. We always use the unemployment rate to measure employment in the city. ${ }^{1}$ In 2015 , the unemployment rate of Changzhou and Shanghai are more than $4 \%$, and the unemployment rates of cities in Zhejiang province are generally more than $2.5 \%$, while the unemployment rate of Jiangsu province is generally less than $2 \%$. It indicates that the developments of job markets in the Yangtze River Delta are not balanced.

\subsection{The Development of the Social Security System in Various Cities Has a Big Gap}

Due to different economic development, there is a big gap between the regions. There are some diff ${ }^{1}$ erences in social security policy. ${ }^{2}$ In 2012, the maintenance of endowment insurance in Shanghai was 43\%, but Jiangsu, Anhui and Zhejiang were 29\%, 36 and 19\%. The rates of pension contributions were $18 \%$ in Shanghai, 17\% in Jiangsu, 20\% in Anhui, and $13 \%$ in Zhejiang. Social security system of different regions showed a greater difference. It increases the difficulty to the integration of social policy of the Yangtze River Delta city group.

\subsection{There Is a Big Gap in Health Service}

${ }^{1}$ In 2015, every 4800 people in Shanghai, 1900 people in Ningbo have a medical institution, which indicates that the number of urban medical institutions in Shanghai is far from the demand of resident population. Every 200 people in Ma'anshan have a health technician, while 116 people in Ningbo have a health technician. It shows that Ma'anshan and other cities provide few medical and health services. The two datas have indicated that the development of medical and health services between different cities in the Yangtze River Delta is not balanced, and the pressure of medical and health services in some cities is relatively large.

\subsection{There Is a Gap between the Development of Education in Cities}

In 2001, in order to optimize the allocation of rural education resources and improve the quality of rural school education, China began to combine the schools for rural areas. ${ }^{2}$ In 2015 , every 800 school-age children shared a school in Hefei, Xuancheng, Zhoushan and other cities, while every 400 students shared a school in Chizhou. Shanghai, Nanjing and other cities are about 1000 pupils have a school, and Wuxi is about 1800 students to share a school. These data shows that there is a gap between the development of compulsory education in various regions.

\subsection{Different Urbans Have Different Housing Security Level}

${ }^{3}$ In 2015, affordable housing area is mostly maintained at around 35 square meters. From this data, we find a balance between cities. However, in 2015, every 420 people enjoy a set of affordable housing in Wuxi, while every 150 people in Shaoxing enjoy a set of affordable housing, 180 people in Ningbo enjoy a set of affordable housing. From this data, Wuxi and other cities have a big pressure in affordable housing.

\section{The Lack of Multiple Subject Responsibilities Leads to the Obvious Gap between the Regional Social Policy}

Based on the welfare pluralism theory, this paper analyses the reasons of different social policies in different city from the government, family and society aspects.

\subsection{From the Point of Government}

\subsubsection{Traditional Administrative Management System Has Obvious Barriers}

Territorial management means that every cities has a clear management boundaries. Yin Zhendong praised the territorial management model to promote the development of China's economy, but also put forward Territorial management led to frequent accidents (Yin, Z. D, 2014). Traditional local government took GDP as the main examination standard. So local government paid most attention to economic benefits, but ignored social benefits.

\subsubsection{The Proportion of Government Financial Investment in Social Policy Services Is Low}

In1994, China had a tax reform, then the central government and local government had unequal pro ${ }^{2}$ perty rights and powers. Local governments attached great importance to economic development, so the local government will take a large number of financial investment to economic construction and neglected social policy. One of the important reasons for this is that the local government finance income is less, and they had to do it.

\footnotetext{
${ }^{12}$ Statistics from Bureau of Statistics of Shanghai, Nanjing, Wuxi, Suzhou, Changzhou, Nantong, Yancheng, Yangzhou, Zhenjiang, Taizhou, Hangzhou, Ningbo, Huzhou, Shaoxing, Jinhua, Zhoushan, Hefei, Wuhu, Ma'anshan, Tongling, Anqing, Chuzhou, Chizhou, Xuancheng.

${ }^{123}$ Statistics from Bureau of Statistics of Shanghai, Nanjing, Wuxi, Suzhou, Changzhou, Nantong, Yancheng, Yangzhou, Zhenjiang, Taizhou, Hangzhou, Ningbo, Huzhou, Shaoxing, Jinhua, Zhoushan, Hefei, Wuhu, Ma'anshan, Tongling, Anqing, Chuzhou, Chizhou, Xuancheng.
} 


\subsection{From a Social Point of View}

\subsubsection{Market Had a Less Role in the Allocation of Resources, Government Had much Role}

Because the government is used to make some decisions in the market, the economic development of our country depends on the support from the government policy to a great extent. As shown in table 1, 2010 to 2015, China's GDP and fiscal revenue and expenditure changes. Data shows that China's GDP growth slowed significantly in the past 6 years. In 2015, it was only 6.9\%. However, with the continuous development of the economy, China's fiscal expenditure is still increasing. From the fiscal expenditure proportion of GDP, we can find that in addition to a small decline in 2014, the other years showed an upward trend. It indicates that the government took more wealth for investment in the national economic and social development expenditure, and the market took less role.

Table 1. 2010 -2015, GDP and fiscal revenue and expenditure in China

\begin{tabular}{lllllll}
\hline & $\begin{array}{l}\text { GDP/ } \\
\text { Billion }\end{array}$ & $\begin{array}{l}\text { Growth rate of } \\
\text { GDP }\end{array}$ & $\begin{array}{l}\text { Fiscal revenue } \\
\text { Billion }\end{array}$ & $\begin{array}{l}\text { Fiscal expenditure / } \\
\text { Billion }\end{array}$ & $\begin{array}{l}\text { Fiscal expenditure } \\
\text { accounts for GDP }\end{array}$ & $\begin{array}{l}\text { Growth rate of fiscal } \\
\text { expenditure }\end{array}$ \\
\hline 20 & 397983 & $10.30 \%$ & 83080 & 89874.16 & $22.58 \%$ & $17.80 \%$ \\
10 & & & 103740 & 108930 & $23.10 \%$ & $21.20 \%$ \\
20 & 471564 & $9.20 \%$ & 117210 & 125712 & $24.21 \%$ & $15.10 \%$ \\
11 & & & & & \\
12 & 519322 & $7.80 \%$ & 129143 & 139744 & $24.57 \%$ & $10.90 \%$ \\
13 & 568845 & $7.70 \%$ & 140350 & 151662 & $23.83 \%$ & $8.20 \%$ \\
14 & 636463 & $7.40 \%$ & 152217 & 175768 & $25.97 \%$ & $15.80 \%$ \\
15 & 676708 & $6.90 \%$ & & & & \\
\hline
\end{tabular}

Source: Statistics and calculation by the National Bureau of statistics, the Ministry of Finance

\subsection{From the Family Point of View}

\subsubsection{High Savings Rate of Households Hindered the Construction of Social Policy Service System}

Wang Yang believes that the high savings rate will bring a series of drawbacks, such as domestic demand (Wang, Y, 2007). In 2015, China's total GDP was 676708 yuan. It had an increase of $6.9 \%$ over the previous year. In the same period, China's household deposits reached 551929 yuan, and it had an increase of $8.9 \%$ over the previous year. The household deposits grew faster than the growth rate of GDP, which means a lot of family paid more attention to savings and reduced consumer demand. Low consumption demand is not conducive to the transformation of China's economic development mode. Residents still believe in the benefits of high savings, and it hinders the construction of social policy service system.

In summary, based on the welfare pluralism theory, this paper has $s$ in-depth analysis of the reasons of hindering the development of social policies from three aspects of government, society and family. The fuzzy responsibilities of government, social and family are not conducive to the construction of social policy service system. In view of the above reasons, this paper will put forward the main solutions.

\section{Clear the Main Responsibilities to Promote the Integration of Urban Social Policy}

Based on the welfare pluralism theory, this paper has a in-depth analysis of the reasons to affect the social policy integration of Yangtze River Delta city group. So there are corresponding countermeasures to the obstacles of social integration policies.

\subsection{Promote the Reform of the Administrative System and Expand the Central Government's Fiscal Responsibility}

\subsubsection{Promote the Reform of Administrative Management System and Change the Concept of Development}

First, we should change the traditional territorial management model and implement the vertical management. Vertical management refers to that the central government shall carry out the organization form of vertical leadership to the branches established by the central government (Shen, R. H, 2009). The vertical management can effectively avoid the disadvantages of lack of coordination of local government and speed up economic and social construction. Second, we should change the concept of development and establish a scientific evaluation system. We should put the results of the construction of social institutions to the assessment of government officials.

\subsubsection{Improve Government Financial Investment in the Construction of Social Policy Service System}

With the development of the concept, the government gradually recognizes the importance of social development and increase investment in social policy development. How to really make the government take the responsibility of the 
development of social policy, this paper considers that we should start from two aspects. Firstly, governments at all levels have their own stable source of income. Wang Yuling believes that the fiscal system should be changed into the classification system. The tax division between the central and local tax should be divided into primary and secondary

(Wang, Y. L, 2009).

Secondly, enhance the financial responsibility of central government and improve the financial transfer payment system. We should reduce the proportion of the central government's financial transfer payments to local governments and expand the levels of government special transfer payments to the next level. At the same time, because of differences in regional economic development in China, the central government should adopt a "differential" policy. Shen Yan and Deng Dasong think that the central financial transfer payment should be reduced financial support to the eastern provinces and expand financial subsidies to the western regions (Shen, Y. \& Deng, D. S, 2015).

\subsection{Market Plays a Decisive Role in the Allocation of Resources}

If we want to promote the construction of the Yangtze River Delta city group, we must rely on the government and market. The market should play a more positive role in the resource allocation. In order to allow enterprises to have more funds into the market and play a positive role in the market, the government should reduce the proportion of fiscal revenue. Enterprises have more funds to participate in the economic and social development.

\subsection{To Stimulate the Consumption of Residents and Reduce the Savings Rate}

Through the study, the biggest reason for high savings is the distrust of people to social policy. Residents can only take personal savings to guarantee the life level. This article believes that family responsibilities should be based on the government's responsibility. The government constantly improves social policy service system by positive policy, and residents can promote economic development by increasing consumption to improve social development policy.

In summary, social policy integration in the Yangtze River Delta city group requires multi subject participation. The reform of government administrative system, fiscal responsibility, the implementation of market function and family consumption capacity will promote the social policy integration of the Yangtze River Delta city group.

\section{Conclusion}

Yangtze River Delta urban agglomeration construction is an important strategy, and achieving social policy integration is essential. This article talks social policy barriers of integration of Yangtze River Delta city group from the employment, social security, health care, education and housing security and other specific aspects. Based on the welfare pluralism theory, this article analyses the reasons of obstacles from the government, the society and the family of three main aspects.

From the government's point of view, on the one hand, territorial management and the central and local responsibility are not conducive to the development of social policy. On the other hand, the government's financial investment in social policy is less. From the social's point of view, the government shared a large number of social development results and society can not bear their own responsibilities. From the family's point of view, the high savings of residents hindered the development of social policy.

In view of the above reasons, this paper puts forward some measures. First of all, the government should promote the reform of administrative management system, and enhance the government's financial investment in the construction of social policy. Second, community has the ability to bear some of the responsibilities. Finally, we should stimulate the consumption of residents and reduce the savings of residents by the continuous improvement and development of social policy service system.

\section{References}

Finance and Economics. (2016). National Development and Reform Commission issued the "Yangtze River Delta Urban Agglomeration Development Plan". Retrieved from http://economy.caijing.com.cn/20160603/4128701.shtml

Lin, J. R., \& Jiang, Z. S. (2008). Research on the local fiscal expenditure policy in the regional integration of the Pan Pearl River Delta. Shandong Economy, 6, 143-154.

GuSongnian, B. A. (2015).Study of China's urbanization innovation evolution and integration of regional. Modern Economic Research, 12, 5-9.

Feng, N. B. A. (2004). Research and development of the regional integration and coordination mechanism of Su zhou, Wu xi and Chang zhou. Areal Research and Development, 3, 4-7.

Xie, H. J. R., \& Wang, W. P. (2016). In the open and the government led regional integration of public governance. Guizhou Social Sciences, 1, 122-127. 
Tong, B. Q. R., \& Chen, C. (2006). Study on regional integration of the eastern region and the three provinces in Northeast China. Scientia Geographica Sinica, 2, 129-135.

Li, J. Y. B. A. (2009). The difficulties and Countermeasures of regional integration work. Journal of Shanghai Customs College, 2, 22-25.

Liu, Z. Z. R., \& Wang, J. L. (2012).Regional integration in the conflict and degradation of the local interests of the Guanzhong. West Forum, 6, 87-92.

Lv Lachang, R., \& Xu, G. Q. (1999).Regional integration in the non-balanced development strategy.Economic Geography, 4, 31-35.

Xu, W. Q. R., \& Duan, X. (2014).From positioning overlap to scientific and technological cooperation. Science \& Technology Progress and Policy, 6, 29-35.

Fang, D. R., \& Sun, M. Y. (2015). Reconstruction of the spatial structure of the Yangtze River Delta city group during the high iron age. Economic Geography, 10, 50-56.

Cai, Y. H. B. A. (2012). Policy cleaning and policy integration: a study of network governance. Journal of Beijing University of Technology, 3, 45-50.

Chen, H. T. B. A. (2014). Responsive governance: Grassroots oriented farmers demand and national policy integration. Journal of Northwest Normal University, 6, 124-129.

Peng, H. M. N. (2009). The frontier of western social welfare theory. Beijing: China Society Press.

Yin, Z. D. B. A. (2014). Vertical management and territorial management: the choice of the administrative system. Economic Research Journal, 4, 41-54.

Wang, Y. B. A. (2007).The reasons, advantages, disadvantages and Countermeasures of the high savings of Chinese residents. HLJ Foreign Economic Relations \& Trade, 5, 106-108.

Shen, R. H. B. A. (2009). Vertical management of government under the background of separation of powers. Chinese Public Administration, 9, 38-43.

Wang, Y. L. B. A. (2009). "Tax sharing system" to "grading system": the optimization of the fiscal management system. Sub National Fiscal Research, 2, 16-22.

Shen, Y. R., \& Deng, D. S. (2015). Under the background of the national co-ordination, regional non-balanced development of basic pension. Hubei Social Sciences, 1, 80-85.

\section{Copyrights}

Copyright for this article is retained by the author(s), with first publication rights granted to the journal.

This is an open-access article distributed under the terms and conditions of the Creative Commons Attribution license which permits unrestricted use, distribution, and reproduction in any medium, provided the original work is properly cited. 